\title{
PENGEMBANGAN MODEL EPIDEMIK SIRA UNTUK PENYEBARAN VIRUS PADA JARINGAN KOMPUTER
}

\author{
Panca Putra Pemungkas ${ }^{1}$, Sutrisno $^{2}$, Sunarsih $^{3}$ \\ ${ }^{1,2,3}$ Department of Mathematics, Diponegoro University, Semarang, Indonesia \\ Email : ${ }^{1}$ putrapanca11@gmail.com, ${ }^{2}$ tresno.math@live.undip.ac.id, ${ }^{3}$ narsih_pdil@yahoo.com
}

\begin{abstract}
This paper is addressed to discuss the development of epidemic model of SIRA (Susceptible-Infected-Removed-Antidotal) for virus spread analysis purposes on a computer network. We have developed the existing model by adding a possibility of antidotal computer returned to susceptible computer. Based on the results, there are two virus-free equilibrium points and one endemic equilibrium point. These equilibrium points were analyzed for stability issues using basic reproduction number and RouthHurwitz Method.
\end{abstract}

Keywords: Basic reproduction number, Routh-Hurwitz method, stability analysis, SIRA model.

\begin{abstract}
Abstrak. Paper ini ditujukan untuk mendiskusikan pengembangan model epidemik SIRA (Susceptible-Infected-Removed-Antidotal) untuk tujuan analisis penyebaran virus pada jaringan komputer. Model dikembangkan dari model sebelumnya dengan menambahkan kemungkinan komputer antidotal dapat kembali menjadi komputer rentan. Berdasarkan hasil-hasil yang diperoleh, terdapat dua titik ekuilibrium bebas virus dan satu titik ekuilibrium endemik. Titik-titik ekulibrium tersebut telah dianalisis kesetimbangannya berdasarkan nilai reproduksi dasar dan metode Routh-Hurwitz.
\end{abstract}

Kata kunci: Bilangan reproduksi dasar, metode Routh-Hurwitz, analisis kestabilan, model SIRA.

\section{PENDAHULUAN}

Virus komputer merupakan suatu program komputer yang dapat menyebar pada komputer atau jaringan komputer dengan cara menginfeksi atau membuat salinan dari dirinya sendiri tanpa diketahui oleh pengguna komputer tersebut. Dalam melakukan proses infeksi atau menyalin dirinya sendiri, sebuah virus memodifikasi program lain sehingga virus tersebut menjadi bagian dari program tersebut, sehingga setiap kali program tersebut dieksekusi, virus akan dieksekusi pula dan menyerang program lain [1].

Masalah yang dihadapi sekarang adalah semakin berkembangnya virus yang ada membuat pengguna komputer yang menginstal antivirus di komputernya tidak menutup kemungkinan komputernya tetap dapat terinfeksi virus atau virus yang sebelumnya sudah ada dapat menyebar atau menyerang sistem keamanan. faktor utama hal ini masalah ini terjadi adalah ketidaktahuan pengguna komputer dalam sistem keamanan komputer. Perusahaan pengantar konten jaringan internet, Akamai yang terletak di Cambridge, Amerika Serikat merilis berbagai statistik tentang trafik internet secara global. Berdasarkan laporan yang berjudul "State of the Internet" mengungkapkan bahwa trafik internet pada kuartal pertama tahun 2013 yang berisi virus terbanyak kedua bersasal dari Indonesia sebanyak $21 \%$ trafik 
internet dari Indonesia bermuatan virus atau malware setelah diperingkat pertama yaitu Cina dengan sebanyak $34 \%$ [2]. Peran penting pemodelan matematika yaitu dalam pengembangan model matematika dapat menjelaskan menjelaskan permasalahan dalam dunia nyata kedalam penyataan matematik [3].

Model epidemik SIR telah banyak dikembangkan oleh matematikawan, contohnya model epidemik SIR pada penyebaran penyakit [4,5], model epidemik SEIR-SEI pada penyebaran virus Zika [6], model epidemik SEIHR pada penyabran virus Ebola [7] dan model epidemik SLBQR pada penyebaran virus computer [8]. Model epidemik SIRA (Susceptible-Infected-Removed-Antidotal) adalah model yang digunakan untuk mengetahui dinamika penyebaran virus komputer dalam suatu jaringan internet dengan memperhatikan adanya subpopulasi Infected atau komputer yang terinfeksi virus [9]. Berdasarkan model matamatika tersebut, penulis memodifikasi model dengan menambahkan parameter yang menyatakan peluang perubahan komputer Antidotal kembali menjadi komputer rentan atau Susceptible.

\section{FORMULASI MODEL}

Model SIRA dalam penyebaran virus komputer pada jaringan komputer dibagi menjadi empat kelas subpopulasi, yaitu subpopulasi Susceptible $(S)$ yang menyatakan kelompok komputer yang tidak terinfeksi virus tetapi memilki peluang untuk terinfeksi virus saat melakukan kontak dengan komputer yang terinfeksi virus. Subpopulasi Infected $(I)$ yang menyatakan komputer telah terinfeksi virus dan dapat menyebarkan kekomputer lain saat melakukan kontak denga komputer tersebut. Subpopulasi Removed $(R)$ yang menyatakan kelompok komputer yang dikeluarkan dari jaringan karena tidak dapat bekerja dengan baik yang diakibatkan oleh virus. Subpopulasi Antidotal $(A)$ yang menyatakan kelompok komputer yang dilengkapi dengan anti virus untuk menangkal penularan virus [4].

Parameter-parameter yang digunakan dalam model antara lain adalah $N$ yang menyatakan proporsi jumlah komputer baru masuk kedalam jaringan. Parameter $\mu$ adalah proporsi rusaknya komputer yang bukan dikarenakan oleh virus. Parameter $\beta$ adalah peluang komputer rentan menjadi komputer terinfeksi setalah adanya kontak. Parameter $\delta$ yang menyatakan proporsi transisi komputer Infected menjadi komputer Removed. Parameter $\sigma$ yang menyatakan proporsi komputer Removed kembali menjadi komputer rentan setelah diperbaiki. Parameter $\gamma$ yang menyatakan peluang transisi komputer Antidotal kembali menjadi komputer rentan. Parameter $\alpha_{S A}$ yang menyatakan proporsi kontrol transisi komputer rentan menjadi komputer Antidotal setelah adanya kontak dan parameter $\alpha_{I A}$ yang menyatakan proporsi kontrol transisi komputer Infected menjadi komputer Antidotal setelah adanya kontak. 


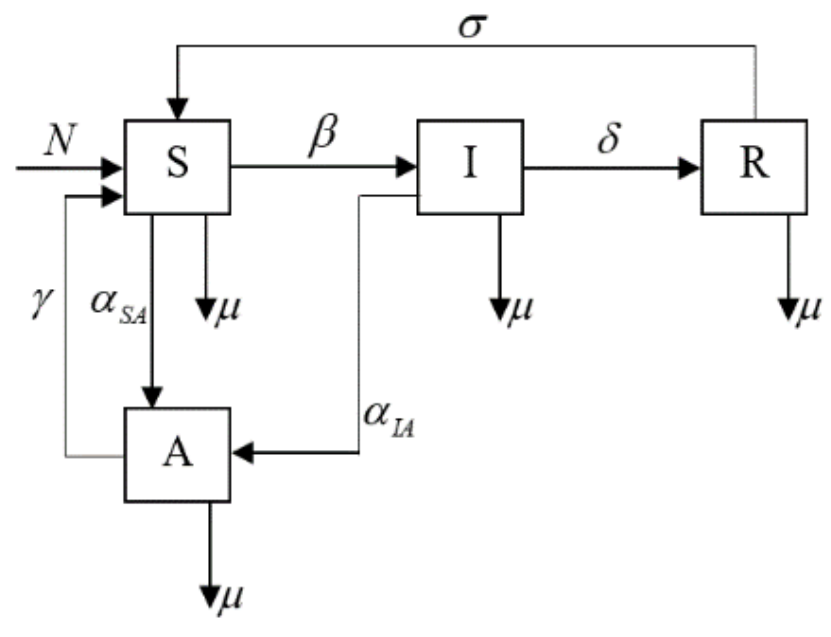

Gambar 1. Transfer dinamik subpopulasi penyebaran virus komputer

Sistem persamaan differensial yang menggambarkan penyebaran virus komputer dalam populasi yang digambarkan pada Gambar 1 diformulasikan sebagai:

$$
\left.\begin{array}{r}
\frac{d S(t)}{d t}=N-\alpha_{S A} S A-\beta S I-\mu S+\sigma R+\gamma A \\
\frac{d I(t)}{d t}=\beta S I-\mu I-\delta I-\alpha_{I A} I A \\
\frac{d R(t)}{d t}=\delta I-\mu R-\sigma R \\
\frac{d A(t)}{d t}=\alpha_{S A} S A+\alpha_{I A} I A-\mu A-\gamma A
\end{array}\right\}
$$

dimana $T=S+I+R+A$ merupakan jumlah seluruh komputer pada suatau jaringan. Sistem (1) disederhanakan dengan mengasumsikan $(N=0)$ dikarenakan penyebaran virus akan lebih cepat dibandingkan perluasan jaringan. Selain itu tingkat kerusakan komputer tanpa pengaruh virus diasumsikan nol $(\mu=0)$ karena tingkat kerusakan komputer tanpa pengaruh virus akan membutuhkan waktu yang sangat lama dibandingkan penyebaran virus dalam jaringan. Sehingga sistem (1) dapat menjadi:

$$
\left.\begin{array}{r}
\frac{d S(t)}{d t}=-\alpha_{S A} S A-\beta S I+\sigma R+\gamma A \\
\frac{d I(t)}{d t}=\beta S I-\delta I-\alpha_{I A} I A \\
\frac{d R(t)}{d t}=\delta I-\sigma R \\
\frac{d A(t)}{d t}=\alpha_{S A} S A+\alpha_{I A} I A-\gamma A
\end{array}\right\}
$$




\section{TITIK KESETIMBANGAN}

\subsection{Titik Kesetimbangan Bebas Virus}

Titik kesetimbangan bebas virus berarti tidak ada komputer yang terinfeksi virus. Keadaan ini terjadi saat jumlah komputer yang terinfeksi adalah nol $(I=0)$, selanjutnya nilai tersebut disubstitusikan kedalam sistem (2). Maka diperoleh dua titik kesetimbangan bebas virus yaitu:

$$
\begin{aligned}
& E_{0}=\left(S_{0}^{*}, I_{0}^{*}, R_{0}^{*}, A_{0}^{*}\right)=(T, 0,0,0) \text { dan } \\
& E_{1}=\left(S_{1}^{*}, I_{1}^{*}, R_{1}^{*}, A_{1}^{*}\right)=\left(\frac{\gamma}{\alpha_{S A}}, 0,0, T-\frac{\gamma}{\alpha_{S A}}\right) .
\end{aligned}
$$

\subsection{Bilangan Reproduksi Dasar}

Bilangan reproduksi dasar atau yang biasa dinotasikan dengan $\left(\mathfrak{R}_{0}\right)$ merupakan parameter yang menunjukan seberapa besar potensi penyebaran virus pada suatu populasi. Pada skripsi ini, untuk mendapatkan nilai $\mathfrak{R}_{0}$ akan dilakukan dengan cara mengkontruksi matriks yang membangkitkan jumlah komputer baru yang terinfeksi. Matriks ini disebut Next-Generation Matrix (NGM). Nilai $\mathfrak{R}_{0}$ diperoleh dengan menentukan nilai eigen dari matriks jacobian yang dihitung dari titik kestimbangan bebas virus. Subpopulasi yang terlibat adalah

$$
\frac{d I(t)}{d t}=\beta S I-\alpha_{I A} I A-\delta I
$$

dengan titik kesetimbangan bebas virus $E_{0}=(T, 0,0,0)$ dan $E_{1}=\left(\frac{\gamma}{\alpha_{S A}}, 0,0, T-\frac{\gamma}{\alpha_{S A}}\right)$.

Next-Generation Matrix (NGM) diperoleh darsubpopulasi yang terinfeksi yang dalam model ini adalah subpopulasi Infected, maka diperoleh:

$$
F(x)=\left[\left(\beta S-\alpha_{I A} A\right) I\right] \text { dan } V(x)=[\delta I] .
$$

Kemudian $F(x)$ dan $V(x)$ dilinierisasi, sehingga diperoleh :

$$
F=\left[\frac{\partial F}{\partial I}\right]=\left[\beta S-\alpha_{I A} A\right] \text { dan } V=\left[\frac{\partial V}{\partial I}\right]=[\delta] .
$$

Next-Generation Matrix (NGM) diperoleh persamaan $\mathfrak{R}_{0}=F V^{-1}$ dengan $V^{-1}=\left[\frac{1}{\delta}\right]$ maka didapatkan $\mathfrak{R}_{0}=\left[\beta S-\alpha_{I A} A\right]\left[\frac{1}{\delta}\right]$ atau $\mathfrak{R}_{0}=\frac{\beta S-\alpha_{I A} A}{\delta}$. Karena pada model ini terdapat dua titik kesetimbangan bebas virua yaitu $E_{0}$ dan $E_{1}$ maka diperoleh dua bilangan reproduksi dasar yaitu $\mathfrak{R}_{01}=\frac{\beta T}{\delta}$ dan $\mathfrak{R}_{02}=\frac{\beta \gamma-\alpha_{I A} T \alpha_{S A}+\gamma \alpha_{I A}}{\delta \alpha_{S A}}$. 


\subsection{Titik Kesetimbangan Endemik}

Keadaan Titik kesetimbangan endemik adalah suatu keadaan dimana terdapat minimal satu komputer yang terinfeksi virus, sehingga dapat menyebarkan virus kekomputer lain. Titik kesetimbangan endemik virus artinya di dalam populasi tersebut terdapat individu terinfeksi virus sehingga $I \neq 0$. Oleh karena itu, kelompok removed juga akan tetap ada, $R \neq 0$ dan kondisi endemik akan tercapai pada saat tidak ada komputer pada populasi antidotal komputer, $A=0$, dari solusi sistem (2) didapat titik kesetimbangan endemiknya adalah

$$
E_{2}=\left(S_{2}^{*}, I_{2}^{*}, R_{2}^{*}, A_{2}^{*}\right)=\left(\frac{\delta}{\beta}, \frac{T-\frac{\delta}{\beta}}{1+\frac{\delta}{\sigma}}, \frac{T-\frac{\delta}{\beta}}{1+\frac{\sigma}{\delta}}, 0\right) .
$$

\section{ANALISA KESTABILAN}

Untuk menganalisis kestabilan dari masing-masing titik kesetimbangan maka dapat dilakukan dengan cara menganalisis kestabilan dari sitem hasil linierisasi sistem (2). Linierisasi sistem (2) menggunakan ekspansi deret taylor orde 1 di sekitar titik kesetimbangan, sehingga diperoleh matriks Jacobiannya yaitu :

$$
J\left(S^{*}, I^{*}, R^{*}, A^{*}\right)=\left[\begin{array}{cccc}
-\beta I^{*}-\alpha_{S A} A^{*} & -\beta S^{*} & \sigma & \gamma-\alpha_{S A} S^{*} \\
\beta I^{*} & \beta S^{*}-\alpha_{I A} A^{*}-\delta & 0 & -\alpha_{I A} I^{*} \\
0 & \delta & -\sigma & 0 \\
\alpha_{S A} A^{*} & \alpha_{I A} A^{*} & 0 & \alpha_{S A} S^{*}+\alpha_{I A} I^{*}-\gamma
\end{array}\right] .
$$

Dari persamaan karakteristik untuk matriks diatas maka dapat diketahui kestabilan dari titik kesetimbangannya.

Karena

\subsection{Kestabilan pada titik kesetimbangan bebas virus}

$$
\begin{aligned}
& \left|\lambda I-J\left(E_{0}\right)\right|=0 \\
& \left|\begin{array}{cccc}
\lambda & \beta T & -\sigma & -\gamma+\alpha_{S A} T \\
0 & \lambda-\beta T+\delta & 0 & 0 \\
0 & -\delta & \lambda+\sigma & 0 \\
0 & 0 & 0 & \lambda-\alpha_{S A} T+\gamma
\end{array}\right|=0
\end{aligned}
$$

maka diperoleh niali eigen dari matriks jacobian sebagai berikut:

$$
\begin{aligned}
& \lambda_{1}=0 \\
& \lambda_{2}=\beta T-\delta \\
& \lambda_{3}=-\sigma \\
& \lambda_{4}=\alpha_{S A} T-\gamma .
\end{aligned}
$$


Teorema 3.1 Misalkan titik kesetimbangan bebas virus $E_{0}$ ada yakni jika $\mathfrak{R}_{01}<1$. Titik kesetimbangan bebas virus $E_{0}$ akan stabil jika $\alpha_{S A} T \leq \gamma$ dan $\mathfrak{R}_{01}<1$.

Bukti : Diketahui $\alpha_{S A} T \leq \gamma$ dan $\mathfrak{R}_{01}<1$ akan ditunjukan bahwa semua nilai eigen matriks jacobiannya yaitu bernilai kurang dari nol. Nilai eigen yang pertama didapatkan sama dengan nol $\left(\lambda_{1}=0\right)$. Nilai eigen yang kedua didapatkan $\lambda_{2}=\beta T-\delta$, sebelumnya telah diketahui bahwa $\mathfrak{R}_{01}=\frac{\beta T}{\delta}$, maka nilai eigen yang kedua dapat ditulis kembali menajdi $\lambda_{2}=\left(\mathfrak{R}_{01}-1\right) \delta$, karena $\mathfrak{R}_{01}<1$ maka nilai eigen $\lambda_{2}<0$. Nilai eigen yang ketiga didapatkan $\lambda_{3}=-\sigma$, karena nilai $\sigma>0$ maka sudah dipastikan bahwa $\lambda_{3}<0$. Nilai eigen yang keempat didapatkan $\lambda_{4}=\alpha_{S A} T-\gamma$, karena nilai $\alpha_{S A}, \gamma>0$ dan $\alpha_{S A} T \leq \gamma$ maka nilai eigen $\lambda_{4} \leq 0$. Oleh karena setiap nilai eigen titik kesetimbangan $E_{0}$ bernilai kurang dari sama dengan nol, maka menurut Teorema 3.1 terbukti titik kesetimbangan bebas virus $E_{0}$ stabil jika $\alpha_{S A} T \leq \gamma$ dan $\mathfrak{R}_{01}<1$.

Karena

$$
\left|\begin{array}{cccc}
\lambda+\alpha_{S A}\left(T-\frac{\gamma}{\alpha_{S A}}\right) & -\frac{\beta \gamma}{\alpha_{S A}} & -\sigma & 0 \\
0 & \lambda-\frac{\beta \gamma}{\alpha_{S A}}+\alpha_{I A}\left(T-\frac{\gamma}{\alpha_{S A}}\right)+\delta & 0 & 0 \\
0 & -\delta & \lambda+\sigma & 0 \\
-\alpha_{S A}\left(T-\frac{\gamma}{\alpha_{S A}}\right) & -\alpha_{I A}\left(T-\frac{\gamma}{\alpha_{S A}}\right) & 0 & \lambda
\end{array}\right|=0
$$

maka diperoleh niali eigen dari matriks jacobian sebagai berikut:

$$
\begin{aligned}
& \lambda_{1}=0 \\
& \lambda_{2}=\frac{\beta \gamma-\alpha_{I A} T \alpha_{S A}+\gamma \alpha_{I A}-\delta \alpha_{S A}}{\alpha_{S A}} \\
& \lambda_{3}=-\sigma \\
& \lambda_{4}=\gamma-\alpha_{S A} T .
\end{aligned}
$$

Teorema 3.2 Misalkan titik kesetimbangan bebas virus $E_{1}$ ada yakni jika $\mathfrak{R}_{02}<1$. Titik kesetimbangan bebas virus $E_{1}$ akan stabil jika $\gamma \leq \alpha_{S A} T$ dan $\mathfrak{R}_{02}<1$.

Karena

\subsection{Kestabilan pada titik kesetimbangan endemik}




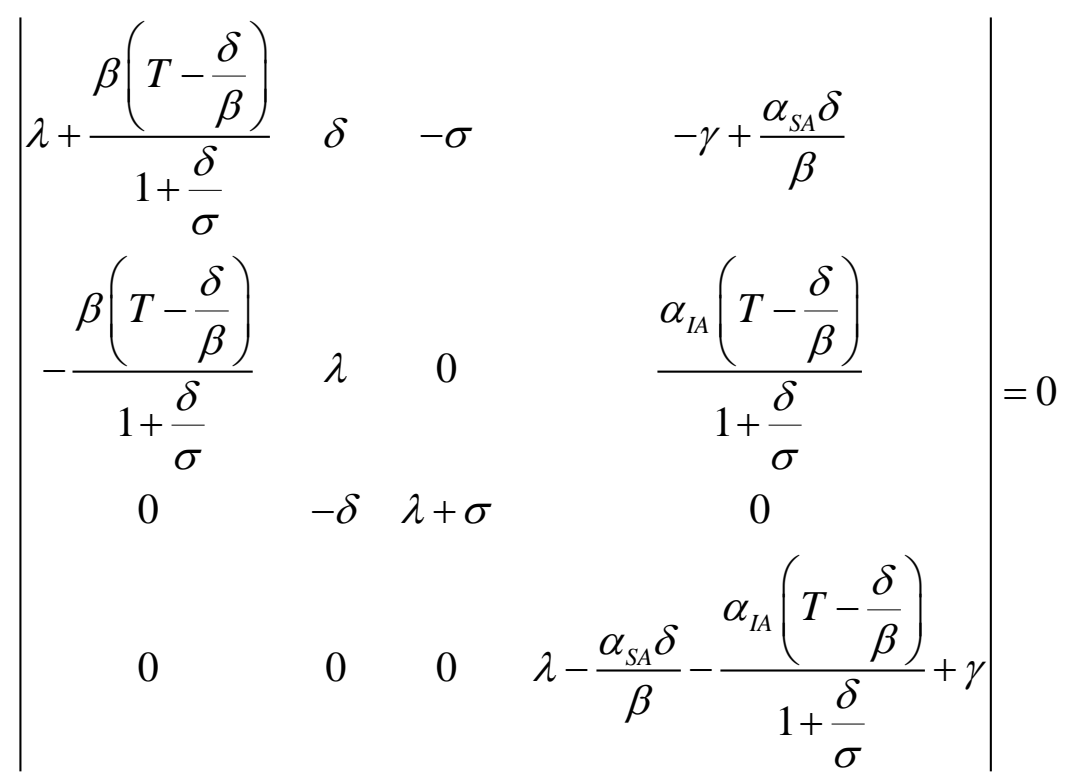

maka, dari matriks jacobiannya diperoleh persamaan karakteristik sebagai berikut:

$$
\begin{aligned}
& \frac{1}{\beta(\sigma+\delta)^{2}}(\lambda)\left(-\alpha_{S A} \delta(\sigma+\delta)-\alpha_{I A} \sigma(\beta T-\delta)+\gamma \beta(\sigma+\delta)+\lambda \beta(\sigma+\delta)\right) \\
& \left(\lambda^{2}(\sigma+\delta)+\sigma \lambda(\beta T+\sigma)+\sigma^{2}(\beta T-\delta)+\delta \sigma(\beta T-\delta)\right)=0 .
\end{aligned}
$$

Teorema 3.3 Misalkan titik kesetimbangan endemik $E_{2}$ ada yakni jika $\mathfrak{R}_{01}>1$. Titik kesetimbangan endemik $E_{2}$ tidak stabil jika dan hanya jika $\alpha_{S A} \delta \geq \gamma \beta$.

Bukti: Diketahui $\mathfrak{R}_{01}>1$ dan $\alpha_{S A} \delta \geq \gamma \beta$, akan dibuktikan bahwa $E_{2}$ tidak stabil. Akan ditunjukan bahwa minimal satu nilai eigen dari matriks jacobiannya bernilai positif. Dari persamaan karakteristik (3) didapatkan nilai eigen sebagai berikut:

Nilai eigen yang pertama bernilai sama dengan nol $\left(\lambda_{1}=0\right)$. Nilai eigen yang kedua diperoleh $\lambda_{2}=\frac{\alpha_{S A} \delta(\sigma+\delta)+\alpha_{I A} \sigma(\beta T-\delta)-\gamma \beta(\sigma+\delta)}{\beta(\sigma+\delta)}$ dan

$$
\begin{aligned}
\lambda_{2} & =\frac{\alpha_{S A} \delta(\sigma+\delta)+\alpha_{I A} \sigma(\beta T-\delta)-\gamma \beta(\sigma+\delta)}{\beta(\sigma+\delta)} \\
& =\frac{\alpha_{I A} \sigma(\beta T-\delta)+(\sigma+\delta)\left(\alpha_{S A} \delta-\gamma \beta\right)}{\beta(\sigma+\delta)} \\
& =\frac{1}{\beta}\left(\frac{\alpha_{I A} \sigma(\beta T-\delta)}{(\sigma+\delta)}+\left(\alpha_{S A} \delta-\gamma \beta\right)\right) \\
& =\frac{1}{\beta}\left(\frac{\alpha_{I A} \sigma\left(\Re_{01}-1\right) \delta}{(\sigma+\delta)}+\left(\alpha_{S A} \delta-\gamma \beta\right)\right) .
\end{aligned}
$$


Karena nilai $\frac{\alpha_{I A} \sigma\left(\Re_{01}-1\right) \delta}{(\sigma+\delta)}$ selalu bernilai positif karena untuk mendapatkan titik kesetimbangan nilai $\mathfrak{R}_{01}$ harus lebih dari satu $\left(\mathfrak{R}_{01}>1\right)$ dan karena $\alpha_{S A} \delta \geq \gamma \beta$ maka nilai eigen $\lambda_{2}$ bernilai positif $\left(\lambda_{2}>0\right)$.

Untuk dua nilai eigen yang tersisa dapat diklasifikasikan dengan persamaan berikut:

$$
\begin{aligned}
& \lambda^{2}(\sigma+\delta)+\sigma \lambda(\beta T+\sigma)+\sigma^{2}(\beta T-\delta)+\delta \sigma(\beta T-\delta)=0 \\
& \lambda^{2}+\sigma \lambda \frac{(\beta T+\sigma)}{(\sigma+\delta)}+\frac{\sigma(\beta T-\delta)(\sigma+\delta)}{(\sigma+\delta)}=0 \\
& \lambda^{2}+\sigma \lambda \frac{(\beta T+\sigma)}{(\sigma+\delta)}+\sigma(\beta T-\delta)(\sigma+\delta)=0 \\
& \lambda^{2}+\sigma \lambda \frac{(\beta T+\sigma)}{(\sigma+\delta)}+\sigma\left(\mathfrak{R}_{01}-1\right) \delta(\sigma+\delta)=0
\end{aligned}
$$

Tanda dari nilai eigen yang merupakan akar dari persamaan (4) tidak mudah ditentukan, sehingga digunakan kriteria Routh_Hurwitz. Berdasarkan [10] yaitu akar-akar karakteristik persamaan (4) bernilai negatif jika dan hanya jika $a_{1}, a_{2}, a_{1} \cdot a_{2}>0$ dengan $a_{1}=\sigma \frac{(\beta T+\sigma)}{(\sigma+\delta)}$ dan $a_{2}=\sigma\left(\mathfrak{R}_{01}-1\right) \delta(\sigma+\delta)$, sehingga diperoleh matriks Hurwitznya sebagai berikut:

Ditunjukan bahwa $a_{1}=\sigma \frac{(\beta T+\sigma)}{(\sigma+\delta)}>0$, karena nilai setiap parameter bernilai positif maka $a_{1}>0$. Ditunjukan bahwa $a_{2}=\sigma\left(\mathfrak{R}_{01}-1\right) \delta(\sigma+\delta)>0$, karena setiap parameter positif dan $\mathfrak{R}_{01}>1$ maka $a_{2}>0$.

Ditunjukan bahwa $a_{1} \cdot a_{2}>0$, karena $a_{1}>0$ dan $a_{2}>0$ maka sudah jelas terlihat bahwa $a_{1} \cdot a_{2}>0$. Oleh karena ada nilai eigen yang bernilai positif dengan memenuhi $\mathfrak{R}_{01}>1$ dan $\alpha_{S A} \delta>\gamma \beta$ maka titik kesetimbangan endemik $E_{2}$ tidak stabil.

\section{KESIMPULAN}

Berdasarkan hasil pembahasan dapat disimpulkan yaitu modifikasi model dengan menambahkan parameter yang menyatakan nilai peluang antidotal komputer kembali menjadi komputer rentan. Persamaan model dinyatakan dalam bentuk sistem persamaan diferensial nonlinier. Perilaku sistem dapat diketahui dengan melakukan analisis kestabilan pada sistem persamaan diferensial terlinierisasi, selanjutnya diperoleh solusi kesetimbangan yaitu titik kesetimbangan bebas virus pertama, titik kesetimbangan bebas virus kedua dan titik kesetimbangan endemic. Kestabilan titik kesetimbangan telah dianalisis dengan bantuan suatu parameter yaitu bilangan reproduksi dasar. Selain itu, telah didapatkan syarat-syarat untuk mencapai kondisi titik kesetimbangan bebas virus pertama stabil dan titik kesetimbangan bebas virus kedua stabil, serta syarat titik kesetimbangan endemik tidak stabil. 


\section{REFERENSI}

[1] Yusianto, Rindra. 2008. Virus Komputer: Teori dan Praktik. Yogyakarta: Graha Ilmu.

[2] Akamai. 2013. The State of The Internet $1^{\text {st }}$ Quarter. Akamai Technologies.

[3] Widowati and Sutimin, Pemodelan Matematika Analisis dan Aplikasinya, Semarang: Undip Press, 2103.

[4] Q. Liu, D. Jiang, N. Shi, T. Hayat. 2018. Dynamiccs of a Stochastics delayed SIR epidemic model with vaccination and double disaeses driven by Levy jumps. Physica A,492.

[5] Hamdan, N. I., \& Kilicman, A. 2018. A fractional orde SIR epidemic model for dungue transmission. Chaos, Solitons and Fractals,144,55-62.

[6] Eber, D., Tosin, M., Americo C. J. 2018. Calibration of a SEIR-SEI epidemic model to describe the Zika virus outbreak in Brazil. Applied Mathematics and Computation, $338,249-259$.

[7] Kabli, K., El Moujaddid, S., Niri, K., \& Tridane, A. 2018. Cooperative system analysis of the Ebola virus epidemic model. Infectious Disease Modelling, 3, 145159.

[8] Fatima, U., Ali, M., Ahmed, N., \& Rafiq, M. (2018). Numerical modeling of susceptible latent breaking-out quarantine computer virus epidemic dynamics. Heliyon, 4(5), e00631.

[9] Piqueira, J. R., \& Araujo, V. O. 2009. A modified Epidemiological model for computer virus. Applied Mathematics and Computation, 213, 355-360.

[10] Merkin, D.R., 1997. Introduction to the Theory of Stability. Springer. New YorK. 